\title{
Physical Activity Participation in Pacific Adolescent Girls with a Physical Disability
}

Caroline Dickson

\begin{abstract}
Health and wellbeing is positively associated with participating in physical activity. However, the little research available suggests that Pacific adolescents with a physical disability are participating in less physical activity in comparison to other groups. Providing an understanding of participation in physical activity for Pacific adolescent girls with a physical disability may, in turn, potentially improve their lifestyles. The purpose of this qualitative research study, which was part of a larger mixed method study, was to address this issue. To increase participation, and reduce sedentary behaviours, factors influencing both participation and how non-participation needed to be considered.
\end{abstract}

A qualitative approach was used to interview seven groups of Pacific adolescent girls (aged 13-24 years) with and without their mothers and 12 providers of services to Pacific girls with a physical disability. An in depth understanding of the factors that inhibited or facilitated participation in physical activity for the Pacific girl who experiences a physical disability, was gained through the participants' stories.

The findings suggested that the girls wanted to participate in physical activity and clearly indicated the physical activities they preferred. Participation was influenced by the interaction of a variety of gender, cultural, age-related (adolescence) and socio-economic factors, together with policy and structural limitations.

To make a change, it is imperative this populace be given priority, while considering the multitude of factors which influence participation. The health and wellbeing of Pacific adolescents with a physical disability is dependent on addressing the factors identified, and a heathier lifestyle incorporating physical activity should be promoted.

Caroline Dickson holds a PhD from Auckland University of Technology and her research focus is adolescent girls. Correspondence: Caroline.Dickson@aut.ac.nz.

\section{Introduction}

Participation in physical activity on a regular basis is important for the physical and psychological wellbeing of all adolescents (Morris, 2008; Shkedy Rabani et al., 2014). In New Zealand, Pacific adolescents are found to be less active in comparison with other ethnic groups (Ministry of Health (MoH), 2008b; Sport New Zealand, 2012). In addition, Pacific adolescents with a physical disability are at greater risk of poor health due to a variety of factors including ineffectually accessing health services (MoH, 2008b).

Opportunities for participation in physical activity for children and adolescents with a physical disability generally are inadequate. While there is a substantial number of adolescents with a physical disability, information relative to participation remains diminutive (Groce, 2004, Van Eck et al., 2008; Maher, William, Old \& Lane 2007; Verschuren, Wiart, Hermans, \& Ketelaar et al., 2012; Fong, Cha, Han \& Au, 
2014). Furthermore, there are no precise guidelines for physical activity frequency, duration and intensity for young people with a physical disability (Maher et al, 2007; Kim, 2009). Participating in physical activity on a regular basis is essential in maintaining normal muscle and joint functioning, improving flexibility and possibly reducing the functional decline related to experiencing a physical disability (Murphy $\&$ Carbone, 2008).

While there are Government initiatives and reports aimed at improving the health and wellbeing of all Pacific adolescents, it is proposed that this subgroup experience greater challenges in comparison to other New Zealand youth (MoH, 2008a). These challenges maybe attributed to the fact that Pacific Youth are less likely to be given a needs assessment or contact the disability services $(\mathrm{MoH}, 2008 \mathrm{a})$. Additionally they may find it challenging to navigate a multifaceted disability support organization (MoH, 2008a).

This significant research gap may be a result of people's lack of awareness and the general attitudes towards people with an impairment (Sport \& Recreation New Zealand, (SPARC), 2005). This study aimed to explore these research gaps through analysing the data and hearing the voices and experiences of the adolescents, their families, and the service providers.

\section{Methods}

\subsection{Participants}

The participants and their families or caregivers were selected from schools, from contacts through service providers, and from information sessions. The providers of services were also selected from contacts and information provided on the internet. The specific inclusion criteria for the girls were that they be Pacific adolescent girls aged from 13-24 years who have experienced a physical disability for more than six months and that they were able to communicate their experiences verbally. The criteria used to select the service providers was that, either directly or indirectly, they be currently involved in providing health and physical activities services to Pacific female adolescent girls who experience a physical disability.

\subsection{Design}

A qualitative descriptive approach method was utilised, which enabled the researcher to gain insights into the phenomena, while staying close to the stories themselves (Sandelowski, 2000). Naturalistic inquiry underpins the philosophy of qualitative description, which aims for a low inference interpretation, promoting hearing and presenting the voices of the participants in their own language (Sullivan-Bolyai, Bova \& Harper, 2005; Sandelowski, 2000). It was essential that the research design and approach was informed by the Pacific worldview, and more particularly that the relationships between physical wellbeing and spiritual, cultural, social, and economic wellbeing are considered (HRC, 2005) as encapsulated in the Fonofale model. The talanoa methodology was deemed to be a culturally appropriate method for this study (HRC, 2005), providing, as it does, the space for shared conversations and reflections. An interview guide was prepared; however, the use of the talanoa ensured considerable flexibility and responsiveness 
to the priority issues raised by the participants (Vaioleti, 2006). The 'talanoa' process utilised face-to-face informal interviews allowing the participants to tell their stories, exchange ideas, or relate their experiences (Vaioleti, 2006).

After ethics approval from The Auckland University of Technology Ethics Committee, the candidate was careful to communicate the underlying principles of the study to the Pacific community, the participants, the participant's parents, and/or the participants' caregivers prior to the interviews. The adolescent and the parent provided consent. It was decided that family-based interviews be conducted and the majority of the interviews occurred in the participants' homes. Pacific adolescents experience close family bonds, and the Pacific family is significant to their way of life $(\mathrm{MoH}, 2010)$. Furthermore, this inclusion of the family gave more depth to the stories.

Seven girls were interviewed, with and without their mothers, in their homes or at a venue of their choice, such as a shopping mall. The type of disability the girl's experienced included spina-bifida, cerebral palsy, C-shaped spine, and as the result of an accident. The researcher and a Pacific research assistant conducted the interviews. Twelve service provider participants were interviewed from eight different groups of disability organisations. They included disability sport foundations and organisations, Pacific disability sport organisations and a school with a disability unit. Information was gathered in interviews or conversations lasting up to 90 minutes. The process of analysing the data began at the commencement of the data collection (at the completion of each of the interviews) (Brown, 2008). Thematic analyses identified patterns by searching for common ideas with similar meaning, and the ideas were then grouped into themes identified by the researchers (Morse $\&$ Field, 1995). Data was processed via the framework approach, using five differing stages of inductive analysis. NVivo was used to assist this process.

\section{Results}

\subsection{Participation}

The findings suggested that the girls had participated in a variety of physical activities during and prior to their adolescent years, but these were primarily individual physical activities, divergent to physical activities involving any team sport or community participation. The physical activities mentioned by the participants included soccer, swimming, dancing, baseball, wheelchair basketball, yoga, Wii Sports (a motion-sensing video game), botchers (a game similar to pétanque), tenpin bowling, gym, shot-put, and walking. Table 1 and 2 show a summary of the key findings from the Pacific adolescent girls and their mothers. The tables include the themes identified from the findings, an explanation of the theme, and the corresponding quote from the participants themselves. Table 1 focuses on participation and non-participation, whereas Table 2 highlights the other contributing factors that impact on the Pacific adolescent girls' experience of physical activity.

Two of the participants were participating in physical activities regularly or meeting the physical activity guidelines of 60 minutes per day of moderate to vigorous activity daily (World Health Organisation (WHO), 2010). This includes adolescents with a 
physical disability; however, they should consult their health professional to identity the frequency, intensity and duration (WHO, 2011) The participants sought, and were interested in participating in, physical activity. However, as with able-bodied adolescents, "fun" was the primary motivation for participation (Sport New Zealand, 2014) (Table 1).When the girls were participating in physical activity habitually, it was apparent they were finding the participation to be beneficial; however, there were multiple layers or precincts attributed to their physical disability that limited participation for the girls. One consisted of disability care requirements preventing participation, and another mentioned that her level of participation "depends on the weather". She preferred walking, but was restricted if the weather was inauspicious (Table 1).

Another participant explained how she had joined a gymnasium; however, her employment commitments needed to take precedence, and therefore, she had difficulty in attending the gymnasium (Table 1). She went on to explain how she would like to participate in shot-put at the Paralympics, but this was not going to be possible as "I need to find a coach". The participants also mentioned their specific disabilities hindered participation. These included spinal operations, participating in physical activity from a wheelchair, and the muscular strength required for running activities. Moreover, most of the participants reported spending a significant amount of time on the computer and Facebook with their friends.

Secondary complications from not engaging in physical activity and having high levels of sedentary behaviour were evident to the providers, and included diabetes, cancer, respiratory problems, muscular atrophy and weakness, heart disease, and obesity. Another provider suggested there was a general concern, centred on good health and longevity for the girls.

Most of the participants mentioned that they were participating or had participated in swimming at some point. It was apparent that due to their physical disability, however, they experienced difficulties in swimming autonomously, mentioning "I am just not an independent swimmer" (Table 1). The providers also identified swimming was another physical activity that the girls participated in, primarily due to the funding allocated to swimming. 


\begin{tabular}{|c|c|c|}
\hline $\begin{array}{l}\text { Physical activity } \\
\text { theme/classification }\end{array}$ & $\begin{array}{l}\text { Description of the } \\
\text { theme/classification }\end{array}$ & $\begin{array}{l}\text { Example of quote from script relating to the } \\
\text { theme/classification }\end{array}$ \\
\hline \multicolumn{3}{|l|}{$\begin{array}{l}\text { PA Participation } \\
\text { Enablers }\end{array}$} \\
\hline $\begin{array}{l}\text { Emotion of fun or } \\
\text { enjoyment }\end{array}$ & $\begin{array}{l}\text { Fun or enjoyment was a primary } \\
\text { motivator to engagement in physical } \\
\text { activity. }\end{array}$ & $\begin{array}{l}\text { I need something that's really fun and exciting } \\
\text { and, something different because that's how I } \\
\text { get motivated in my sports. }\end{array}$ \\
\hline $\begin{array}{l}\text { Emotion of feeling } \\
\text { good }\end{array}$ & $\begin{array}{l}\text { Having a sense of feeling good while } \\
\text { participating in PA. }\end{array}$ & Wheelchair basketball makes her feel "good". \\
\hline $\begin{array}{l}\text { Variety of PA } \\
\text { available at school }\end{array}$ & $\begin{array}{l}\text { A variety of PA available at school to } \\
\text { participate in. }\end{array}$ & $\begin{array}{l}\text { There are lots and lots of sports...bocce, soccer; } \\
\text { bowling...you does some kind of sports everyday } \\
\text { don't you. }\end{array}$ \\
\hline Dancing & $\begin{array}{l}\text { Participating in and having Island } \\
\text { dancing available. }\end{array}$ & $\begin{array}{l}\text { I like island dancing. Other than that, I don't } \\
\text { like other dancing. }\end{array}$ \\
\hline $\begin{array}{l}\text { Physiotherapist } \\
\text { encouraging } \\
\text { swimming }\end{array}$ & $\begin{array}{l}\text { The physiotherapist encouraged the } \\
\text { adolescent girl to participate in } \\
\text { swimming to for the purpose of } \\
\text { strengthening her muscular system. }\end{array}$ & $\begin{array}{l}\text { I told my physio, and he told me to tell my } \\
\text { parents that I should try swimming, and that's } \\
\text { when I started doing swimming. }\end{array}$ \\
\hline $\begin{array}{ll}\text { Watching } & \text { Para } \\
\text { Olympic sport }\end{array}$ & $\begin{array}{l}\text { Watching perceived role models } \\
\text { encourages participation in PA. }\end{array}$ & $\begin{array}{l}\text { I was watching the para Olympics - they do like } \\
\text { weightlifting and stuff, it's just something } \\
\text { interesting and new. }\end{array}$ \\
\hline $\begin{array}{l}\text { Access to } \\
\text { participation }\end{array}$ & $\begin{array}{l}\text { Others can assist with access to } \\
\text { participation. }\end{array}$ & $\begin{array}{l}\text { A volunteer would come from XXX would come } \\
\text { and pick us up every Tuesday to go do } \\
\text { wheelchair basketball. }\end{array}$ \\
\hline \multicolumn{3}{|l|}{ Inhibitors } \\
\hline $\begin{array}{l}\text { Limitations due to } \\
\text { disability }\end{array}$ & $\begin{array}{l}\text { Appointments such as the spinal } \\
\text { unit compete with physical activity } \\
\text { participation. }\end{array}$ & $\begin{array}{l}\text { She can't play this week as we have to work out } \\
\text { at the spinal unit. }\end{array}$ \\
\hline $\begin{array}{l}\text { Physical activities } \\
\text { not available }\end{array}$ & $\begin{array}{l}\text { Not able to access physical activity, } \\
\text { or continue to play in sports due to } \\
\text { unavailability. }\end{array}$ & $\begin{array}{l}\text { Yeah, so that would be good if they had } \\
\text { activities like soccer and things, yeah, if I could } \\
\text { find a place to play them. }\end{array}$ \\
\hline $\begin{array}{l}\text { Physical activity is } \\
\text { weather dependant }\end{array}$ & $\begin{array}{l}\text { If the weather is not conducive, } \\
\text { walking with a physical disability is } \\
\text { problematic. }\end{array}$ & It depends on the weather. \\
\hline Time constraints & $\begin{array}{l}\text { Busy with other activities including } \\
\text { working. }\end{array}$ & $\begin{array}{l}\text { I've actually joined the gym...But the thing is I } \\
\text { haven't been there for a couple of months } \\
\text { because I've been so busy with work. }\end{array}$ \\
\hline $\begin{array}{l}\text { Unable to find a } \\
\text { coach }\end{array}$ & $\begin{array}{l}\text { Wanting to join the Paralympics, } \\
\text { but there is no coach available to } \\
\text { the participant. }\end{array}$ & $\begin{array}{l}\text { Um, because I'm trying to make it to the para } \\
\text { Olympics in } 2016 \text { so...Um I'm looking for a } \\
\text { coach. }\end{array}$ \\
\hline $\begin{array}{l}\text { Needing assistance } \\
\text { to assist swimming }\end{array}$ & $\begin{array}{l}\text { Other students or support people are } \\
\text { needed to assist with swimming. }\end{array}$ & $\begin{array}{l}\text { Two yeah year } 6 \text { students would always have to } \\
\text { swim with me but I'm just not an independent } \\
\text { swimmer. }\end{array}$ \\
\hline 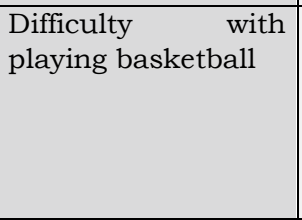 & $\begin{array}{l}\text { Enduring difficulties with balls } \\
\text { bouncing around with girls while } \\
\text { they are in a wheel chair and or/ } \\
\text { mixed gender teams with unequal } \\
\text { capabilities. }\end{array}$ & $\begin{array}{l}\text { I tried basketball, but I was scared of the ball, } \\
\text { so I stopped going...I hate throwing balls, but } \\
\text { the stink thing was it was all just men. It was } \\
\text { men, and there were only two girls on it - yeah } \\
\text { and so that's why I didn't play because I was } \\
\text { scared of the men. }\end{array}$ \\
\hline
\end{tabular}


Motivation was also raised by the providers when they explained how it could at times be challenging to enthuse disabled people. Another matter mentioned by a provider was how the girls themselves may be too self-conscious to participate in in some physical activities, such as rowing. This may be due to the fact that the girls needed to be lifted from their wheelchairs, placed on the floor, and then placed into the boats, while other people were watching. As a consequence, the girls become self-conscious and uncomfortable.

\subsection{Other factors}

\subsubsection{Social friends/curse}

Friends were identified as having a significantly positive role, encouraging the girls in participation in physical activity (Table 2). Most of the participants referred to engaging in physical activity with their peers intensifying the fun or enjoyment factor, and it was found teachers also may have influenced or encouraged social interaction. The girls explained "I'm more comfortable with my friends". Providers also mentioned how the girls could be shy and socially inept, which may have a negative impact on their socialisation skills.

Furthermore, while not specifically asked, the providers also mentioned how the girls could be seen as a curse in their culture. This issue was raised in most of the interviews with the girls too (Table 2). In addition to socially isolating the girls, this could cause them to have to endure seclusion at home. This seclusion may lead to not participating in physical activity and higher levels of sedentary behaviours. The providers also suggested that the girls were not going to want to access services including physical activity if they were experiencing this belief in their families.

\subsubsection{Parents}

There is high regard and respect for the family amongst the Pacific peoples' culture $(\mathrm{MoH}, 2010)$. While developmentally seeking autonomy, the adolescent with a physical disability is primarily dependant on parents and family for support, including encouragement and transport to enable them to participate in physical activity.

The girls in this study clarified how it was their preference to be able to participate in physical activity independently, but their parents were too protective, therefore restricting them from participating in physical activity. One participant mentioned "she's real protective...she thinks I can't do anything" (Table 2). One mother was also conscious of her daughter becoming a hindrance in team sport due to her disability.

It could also be an issue for the family to attempt to provide for one family member if it was going to impact on the rest of the family's needs. However, some providers suggested that the family attitudes needed to change, which may be perplexing due to opposing challenges, such as time, access issues, and culture. The families may have had other financial commitments too, such as to their church, which placed a strain on the family finances.

\subsubsection{Transport}

Transport was identified as a significant barrier to participation in physical activity. This was due to the time needed to access the activities, the absence of transport, 
funding and the distance to physical activities (Table 2). While some families do manage this: for example, "my husband and I; we take turns", it is evidently problematic for some "My mum has no excuses...oh we drive you around too much...when they don't".

\subsubsection{Benefits}

The participants reported that participating in physical activity had benefited their physiological and psychological wellbeing. They did not specifically describe the benefits of participation in biomedical terms; however, in their own words, they clearly had an understanding of how participating in physical activity had an advantageous effect on their general health and wellbeing (Table 2). Other participants also mentioned how swimming relieved them from extended periods their wheelchairs.

\subsubsection{Policy}

In the wider context, the participants and their families were dependent on community and government policy, which enhanced or impeded their access to participation in physical activity. The issues raised that were identified as having a connection to government policy were access to the physical activity via transport and disability funding and for the unique equipment necessary to play sports such as wheelchair basketball. However, there appeared to be confusion or uncertainty around entitlements and where and when to apply for funding. The providers also relayed the problems associated with the costs of participating in physical activity. They mentioned how this may impede participation when there were costs associated with travel, programmes, joining clubs, gymnasium memberships, lessons, or coaching.

\subsubsection{Sports club/gymnasiums}

It was found that sports organisations or gymnasiums attempted to engage physically disabled adolescents. However, engaging the physically disabled adolescent into mainstream sports clubs could be challenging for the clubs themselves, as they did not have the experience of accommodating physically disabled adolescents.

Moreover, the equipment needed to be modified specific to the girls' disability. While some of the equipment could be shared, some equipment, like the boats, required modification, was expensive or simply not available. In particular, one provider mentioned how the adolescents could travel to play wheelchair basketball, but upon arrival, the wheelchairs might be either unavailable or the wrong size.

\subsubsection{Dance}

Dance programmes, particularly contemporary dance workshops, were available to the girls. However, not many girls attended them because they preferred forms of dance specific to their own culture, such as Pacific dance. Consequently, one provider created a Pacific dance group for the girls to enjoy (Table 1).

\subsubsection{Schools/physiotherapist}

Schools and physiotherapists that had daily contact with students provided a pathway for the girls to access physical activity through referrals to service 
providers. However, providers also acknowledged difficulties in communication resulting from language barriers (Table 1).

One provider explained that the environment of the school, including how culture or perception of school employees within that environment is managed, could influence the adolescents' participation in physical activities. Inclusion was also dependant on how many disabled adolescents there were, and if including them with able-bodied adolescents was going to prove detrimental.

\begin{tabular}{|c|c|c|}
\hline $\begin{array}{l}\text { Physical activity } \\
\text { theme/classification }\end{array}$ & $\begin{array}{l}\text { Description of the } \\
\text { theme/classification }\end{array}$ & $\begin{array}{l}\text { Example of quote from script relating to the } \\
\text { theme/classification }\end{array}$ \\
\hline Social/friends & & \\
\hline
\end{tabular}

\begin{tabular}{|c|c|c|}
\hline $\begin{array}{l}\text { Companionship while } \\
\text { participating }\end{array}$ & $\begin{array}{l}\text { Preference is for friends to } \\
\text { participate in physical activity } \\
\text { due to companionship. }\end{array}$ & $\begin{array}{l}\text { What I've noticed with the girls is they like to } \\
\text { do things together. }\end{array}$ \\
\hline Fun with friends & Activity is fun with friends. & She's had fun, you know with the other kids. \\
\hline $\begin{array}{l}\text { Comfortable participating } \\
\text { with friends }\end{array}$ & $\begin{array}{l}\text { More comfortable participating in } \\
\text { physical activity with friends. }\end{array}$ & $\begin{array}{l}\text { I'm more comfortable with my friends. } \\
\text { It helps people make new friends and } \\
\text { socialising. }\end{array}$ \\
\hline Confidence & $\begin{array}{l}\text { Participating with friends help } \\
\text { to build confidence. }\end{array}$ & $\begin{array}{l}\text { I'd be more confident if I knew there was } \\
\text { someone else I knew who played netball in } \\
\text { the same team". }\end{array}$ \\
\hline Friends provide transport & $\begin{array}{l}\text { Friends are able to provide } \\
\text { transport. }\end{array}$ & $\begin{array}{l}\text { My friends and they take me because they } \\
\text { are mobile. }\end{array}$ \\
\hline Inability to find friends & $\begin{array}{l}\text { Finding other Pacific } \\
\text { adolescent girls. }\end{array}$ & $\begin{array}{l}\text { It's a pity that we haven't come across any } \\
\text { other teenage Pacific Island kids. }\end{array}$ \\
\hline Parents & & \\
\hline $\begin{array}{l}\text { Family perceptions of } \\
\text { physical activity }\end{array}$ & $\begin{array}{l}\text { More likely to participate if their } \\
\text { parents perceive it is the norm. }\end{array}$ & $\begin{array}{l}\text { My family is sporty so I've come to love each } \\
\text { sport. }\end{array}$ \\
\hline Parents attitudes & $\begin{array}{l}\text { Parents attitudes, and or } \\
\text { perceived value }\end{array}$ & It's important for the parents to support them. \\
\hline $\begin{array}{l}\text { Inhibitors } \\
\text { Parents attitudes }\end{array}$ & $\begin{array}{l}\text { Parents deleterious attitudes to } \\
\text { their daughters participating. }\end{array}$ & $\begin{array}{l}\text { When I was little and they played basketball, } \\
\text { my parents wouldn't take me coz they just } \\
\text { thought I was an object. }\end{array}$ \\
\hline $\begin{array}{l}\text { Parental pressure to other } \\
\text { commitments }\end{array}$ & $\begin{array}{l}\text { Parents' expectations that their } \\
\text { daughters need to commit to } \\
\text { other responsibilities. }\end{array}$ & $\begin{array}{l}\text { I'm only one person and there's only } 24 \text { hours } \\
\text { in a day and you want me to do all of this. } \\
\text { Yeah, so you just have to balance them to keep } \\
\text { them happy so they don't drive you nuts all } \\
\text { day. }\end{array}$ \\
\hline Parents too protective & $\begin{array}{l}\text { Parents are not permitting their } \\
\text { daughters to participate in } \\
\text { activities as they feel a necessity } \\
\text { to protect them. }\end{array}$ & $\begin{array}{l}\text { I'd love to go and do more things but it's just } \\
\text { my mum. } \\
\text { She'll be like; no you can't do this you can't do } \\
\text { that. } \\
\text { She's real protective... she thinks I can't do } \\
\text { anything. }\end{array}$ \\
\hline $\begin{array}{l}\text { Not allowing their daughters } \\
\text { to participate in mainstream } \\
\text { sports. }\end{array}$ & $\begin{array}{l}\text { Protecting their daughters by } \\
\text { not allowing them to }\end{array}$ & $\begin{array}{l}\text { I don't want her to be saying that she's holding } \\
\text { everybody back...I am kind of protective. }\end{array}$ \\
\hline
\end{tabular}




\begin{tabular}{|c|c|c|}
\hline & $\begin{array}{l}\text { participate in team sports } \\
\text { with able-bodied adolescents. }\end{array}$ & \\
\hline \multicolumn{3}{|l|}{ Transport } \\
\hline $\begin{array}{l}\text { Parents driving their } \\
\text { daughters to physical } \\
\text { activities }\end{array}$ & $\begin{array}{l}\text { Parents are able to transport their } \\
\text { daughters to physical activities } \\
\text { and can manage other family } \\
\text { commitments. }\end{array}$ & $\begin{array}{l}\text { I drive her there... My husband and I; we take } \\
\text { turns. }\end{array}$ \\
\hline $\begin{array}{l}\text { Parents not transporting } \\
\text { their daughters }\end{array}$ & $\begin{array}{l}\text { The daughters perceiving their } \\
\text { parents are not driving them to } \\
\text { activities. }\end{array}$ & $\begin{array}{l}\text { And my mum has no excuses of oh we drive } \\
\text { you around too much when they don't! }\end{array}$ \\
\hline \multicolumn{3}{|l|}{ Benefits to physical activity } \\
\hline Perceived benefits & $\begin{array}{l}\text { Participating in physical activity } \\
\text { is beneficial for their } \\
\text { psychological and physiological } \\
\text { wellbeing. }\end{array}$ & $\begin{array}{l}\text { It's good for relaxation and gets the stress out } \\
\text { of my system, kind of relieves my anger, my } \\
\text { frustration... Its help build } \\
\text { confidence......stamina and my balance. } \\
\text { My legs feel stronger, relaxes my muscles. }\end{array}$ \\
\hline \multicolumn{3}{|r|}{ 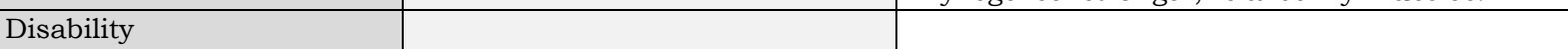 } \\
\hline $\begin{array}{l}\text { Perception physical activity } \\
\text { benefits their disability }\end{array}$ & $\begin{array}{l}\text { Partaking in physical activity } \\
\text { specifically alleviates their } \\
\text { disability. }\end{array}$ & $\begin{array}{l}\text { They said I had to be active in everything that I } \\
\text { do so my muscles in my legs don't shrink or } \\
\text { that's what they said. }\end{array}$ \\
\hline $\begin{array}{l}\text { Parents attitude to their } \\
\text { daughter's disability }\end{array}$ & $\begin{array}{l}\text { Parents motivating their } \\
\text { daughters and having a sense } \\
\text { that their disability should not } \\
\text { prevent them from participating } \\
\text { in activities. }\end{array}$ & $\begin{array}{l}\text { It's just motivating the kids; letting them know } \\
\text { that just } \operatorname{coz} \text { your disability, shouldn't limit you. }\end{array}$ \\
\hline $\begin{array}{l}\text { Partaking in physical } \\
\text { activity with a physical } \\
\text { disability }\end{array}$ & $\begin{array}{l}\text { Due to the physical demands of } \\
\text { physical activity participation, the } \\
\text { participants explicated some of } \\
\text { the difficulties included how they } \\
\text { tire easily, have problems } \\
\text { standing, having a sense they will } \\
\text { injure themselves, their muscular } \\
\text { system. }\end{array}$ & $\begin{array}{l}\text { You get tired after the } 2 \text { or } 3 \text { hours. } \\
\text { It becomes a problem with the standing. } \\
\text { I could break something... Since my muscles } \\
\text { have stopped working, I can't properly do that } \\
\text { now. } \\
\text { Since I got my spinal operation I haven't been } \\
\text { swimming in ages...My legs are quite weak so". }\end{array}$ \\
\hline $\begin{array}{l}\text { Cultural and perceptions } \\
\text { due to their disability } \\
\text { Attitude }\end{array}$ & $\begin{array}{l}\text { Some people view the Pacific } \\
\text { adolescent girls as a burden due } \\
\text { to their disability. }\end{array}$ & $\begin{array}{l}\text { The child is seen more as a burden, yeah } \\
\text { (sigh). In Samoa, if you are disabled you're not } \\
\text { allowed to go out; it's kind of an } \\
\text { embarrassment. Yeah, it's kind of like they } \\
\text { think it's a curse, like God cursed them. }\end{array}$ \\
\hline $\begin{array}{l}\text { Perceptions of disability } \\
\text { competing with time and } \\
\text { finances }\end{array}$ & $\begin{array}{l}\text { Families struggle to } \\
\text { accommodate their daughter who } \\
\text { experiences a physical disability } \\
\text { as this places stress on family } \\
\text { time and finances. }\end{array}$ & $\begin{array}{l}\text { When they found out I had a disability, they } \\
\text { thought it would be a straight burden on their } \\
\text { financial side. And so pretty much they just } \\
\text { saw me as a, what do you call those people } \\
\text { that, not dumb but, what do you call those } \\
\text { people that you look at them and they just look } \\
\text { blank? If you're forever fighting it and feeling } \\
\text { that it is a burden then there is no motivation. }\end{array}$ \\
\hline
\end{tabular}

\section{Discussion}

Previous research and information specific to Pacific adolescent girls' experience with a physical disability is limited. This is of concern due to the increasing numbers of reported Pacific peoples with a physical disability (MOH, 2008a). The findings showed that the girls wanted to participate in physical activity and indicated clearly the physical activities they preferred. However, their participation was influenced by the interaction of a variety of personal and environmental factors together with policy and structural limitations. 


\subsection{Participation in physical activity}

All the Pacific girls with a physical disability who were interviewed had, at some stage, participated in physical activity with differing levels of intensity, duration, and frequency. However, at the time of the interviews two of the girls were meeting the recommended physical activity guidelines (SPARC, 2007; WHO, 2010) and five of the girls' sedentary behaviours were too high, (or over two hours per day), placing them at risk for poorer health. This is comparable with other studies which also suggest adolescents with a physical disability are spending extended hours in sedentary behaviours (Shkedy Rabani et al., 2014; Nooijen et al., 2014). Theoretically, these high sedentary behaviours may have an adverse effect on their health, including their metabolic and cardiovascular systems (Taylor, 2014). Lower levels of physical activity participation have also been noted in other population groups of adolescents who experience a physical disability (Nooijen et al., 2014; Fong et al., 2014).

However, the inactive participants did express a concern around inactivity, articulating a need to participate more regularly. Results showed multiple personal, family and environmental enablers and inhibitors to physical activity and sedentary behaviours. This finding is comparable with Palisano et al. (2011) who argue participation for the physically disabled adolescent is dependent on multiple family and environmental factors. Findings from this study suggest that the girls prefer and enjoy swimming, wheelchair basketball, and Pacific dancing with their peers. Other preferred activities included soccer, baseball, yoga, wii sports (computer video game), botchers (similar to pétanque), tenpin bowling, gym, shot put, and walking. This finding is in line with existing literature which suggests Pacific adolescent girls who did not experience a physical disability showed preferences for swimming, walking, athletics, running, touch, netball, dance, cycling, basketball, and volleyball (Sport New Zealand, 2012).

Most of the girls from the qualitative interviews were not involved regularly in organised sport. This is consistent with findings from Packer et al. (2006), who reported that the physically disabled adolescents from their study rarely participated in sport outside of school hours. They suggested that the physical activity organisations were unaware of how to accommodate physically disabled adolescents (Packer et al., 2006). In this study, if the girls were participating in wheelchair basketball, it was the norm to find it necessary to play in a mixed gender team of mixed abilities including men of differing ethnic groups, who they found to be more competitive. Whenever possible, teams of equal gender and ability should be organised.

Enjoyment is a well-documented factor for determining physical activity participation (Fong et al., 2014). Engel-Yeger et al. (2009) also found that the girls who experienced cerebral palsy $(\mathrm{CP})$, in comparison to the able-bodied adolescents, were the group who reported the highest levels of enjoyment. Consistent with the previous research findings, this study found enjoyment and socialisation opportunities positively influenced participation in physical activity. The attitudes of others, unavailable peers or girls they prefer to participate with, and challenges to their self-esteem were the main factors impacting on enjoyment while participating. Choice or preference was also an important predictor inspiring participation. This study, found that while some schools accommodate the girls, thereby encouraging participation, gymnasiums, and access issues, restrict their 
preferences. The school environment, where physical activity is compulsory until year 10, may provide an opportunity for the girls to attempt a variety of physical activities, which may, in turn, widen their preferences. Some schools had attempted to accommodate girls in physical activity; however, it was noted that all teachers should receive training on engaging in culturally safe practice to promote participation and access.

Findings also suggest that a number of the physical activities themselves require some level of physical fitness, which is problematic for the girls as a result of their impairments. Equally, the impairments were challenging for the girls when they experienced muscular, and limb weakness, were recovering from operations, or experienced other medical complications or difficulties, such as attempting to participate. These included changing into physical activity attire, attempting to participate in physical activity from a wheelchair, or finding standing is tiring, and running problematic. Furthermore, the girls may also be reliant on others to assist them in some activities, such as swimming, which may be problematic. In comparison, Blinde and McCallister (1999) also reported that girls or women with a physical disability are faced with multiple challenges while attempting to engage in physical activity, including the physical constraints attributed to the disability itself.

The inherent nature of the disability may have impeded participation in earlier physical education training, thereby limiting their skills. Therefore, the physical activities need to be instituted, with regard to the individual's needs, by skilled facilitators and instructors. Considerations should include the girl's needs, abilities and preferences, and the physical activity should be safe and enjoyable, preferably with friends. Moreover, Pacific people's health belief systems are embedded in a multifaceted arrangement of cultural principles which impact on their daily lives (Fairbairn-Dunlop et al., 2014). Therefore, healthcare workers and physiotherapists, who have regular contact with the girls, may provide opportunities for the girls and their family, but need to be culturally responsive.

As one provider mentioned, the girls were sometimes not assertive, and reliant on others to speak out in regard to their needs, and if their English is their second language, this may make communication problematic for the adolescent with a physical disability. This reticence, no doubt stems from Pacific adolescents' traditional respect for authority figures, and this may impede the girls' communication skills when endeavouring to deal with challenges, such as making enquiries about engaging in physical activity (Statistics New Zealand and Ministry of Pacific Island Affairs, 2011).

\subsection{Role models/coaches/motivation}

Findings suggest role models encourage participation and, similarly, watching Paralympic sports or other Pacific people competing may also encourage physical activity. Positive role modelling is important for identity development, and it instils a sense of achievement for physically disabled adolescents (Tuffrey, 2013).

Some of the participants also mentioned motivational difficulties. While motivation may be linked to the severity of the disability, the literature suggests that by increasing awareness of the health benefits of physical activity and allowing for more choice of activities, the difficulties around intrinsic motivation may be overcome (Kosma, Cardinal \& Rintala, 2002). 


\subsection{Peers/inclusion}

While adolescents with physical disabilities have a preference for participating in physical activity with their friends, it is the norm to experience social exclusion as they age as a result of their physical disability (Tuffrey, 2013). The girls may perceive engaging in physical activity as a venue for enjoying and spending time with their friends and, furthermore, creating lifelong friendships. This may be attributed to their peer groups creating a supportive environment, intensifying the enjoyment factor, encouraging adherence, normalising the activity, providing transport, and generating confidence, comfort and companionship.

Counselling services specific to girls are necessary to help overcome some of these socialisation and self-esteem issues, permitting skills to overcome their psychological barriers and foster resilience (Pudney, 2014). If possible, the counsellors should be of an ethnic group preferable to the girls themselves to avoid therapeutic resistance.

\subsection{Parents}

The findings from this study show the girls were dependent on their parents for their general health and wellbeing. It is important, therefore, that any support or consultation should be directed at the family to strengthen the families' resilience. This is consistent with findings from KristĖn, et al. (2003), who suggested parents have a significant role in supporting the adolescent with a physical disability. Furthermore, the family dynamics may impede participation for the girls if they have other siblings also requiring care and, additionally, if the girls are a low priority in the family. Generally, Pacific people are within the lower socio-economic groups, and socioeconomic determinants exert a strong influence on family expenditure $(\mathrm{MOH}, 2008 \mathrm{~d})$. As identified by the participants, participating in physical activity is sometimes beyond the financial resources of the family. To increase participation, organisations need to consider these restraints and promote physical activity that may potentially be within the family budget and preference.

\subsection{Policy}

Government policies or initiatives were found to be instrumental in influencing participation in physical activity. New programmes encouraged participation, with the girls having a sense that they wanted to 'try out' the new activity. Government initiatives targeted at this level and benefiting physical activity participation included providing information, services, disability cards, special equipment, funding for physical activities, and some transport. However, government funding to the service providers was limited, and they need to demonstrate sustainability. Despite advances in international laws and policy, minimal attention has been directed at Pacific girls with a physical disability (Bhabha, 2013).

Pacific groups regard family, culture, and spirituality as the most important concepts to themselves (MOH, 2008d). This study found that physical activity time often competes with other family commitments, such as looking after siblings and attending church. Therefore, to ensure participation, any physical activity programmes need to accommodate these obligations. In comparison to European adolescents, Pacific adolescents are up to four times more likely to attend church (Mila-Schaaf et al., 2008). The church may be a forum in which respected Pacific elders can promote the benefits of increasing physical activity and reducing 
sedentary behaviours. Bopp, Peterson \& Benjamin (2012) found that faith-based interventions have the potential to increase physical activity and consequently improve health outcomes.

\subsection{Stigma related to the physical disability}

"There is a need to address the disability stigma and discrimination against peoples within Pacific families and all parts of the Pacific community, including the church" (MOH, 2010, p. 12). If the girls are experiencing this stigma, it is imperative that it should be managed to ensure participation in physical activity and other daily activities. While government initiatives are aiming to address this issue, one provider explained that these initiatives were not reaching the people concerned. Counselling services for the girls may assist them to overcome this discrimination, allowing more resilience for the girls and acceptance from the family.

\section{Limitations}

Data was based on self-reported information from the adolescents, their mothers and service providers. The candidate reflected on the findings, analysis, and interpretation with the candidate's supervisors and Pacific research assistant to limit the amount of personal bias.

In conclusion, to increase participation, future interventions should consider facilitators and barriers when implementing programmes. The physical activity needs to be enjoyable, accessible and culturally appropriate. While they may have to endure their physical disability throughout their lives, habitual physical activity may improve the girls' general physiological and psychological health and wellbeing through to late adulthood.

Acknowledgements: To Associate Professor Erica Hinckson my primary supervisor and Professor Peggy Fairbairn-Dunlop my secondary supervisor who supported me throughout the research study. 


\section{References}

Bhabha, J. (2013). Adolescents: Current rights for future opportunities. South Cooperation for Child Rights Working Paper, 2. Retrieved from https://www.unicef.org/eapro/Working_paper_2___Adolescents.pdf

Blinde, E. M., \& McCallister, S. G. (1999). Women, disability, and sport and physical fitness activity: The intersection of gender and disability dynamics. Research Quarterly for Exercise and Sport, 7O(3), 303-312. Retrieved from http://journals.sagepub.com/doi/abs/10.1177/1012690215577398

Bopp, M., Peterson, J. A., \& Webb, B. L. (2012). A comprehensive review of faith-based physical activity interventions. American Journal of Lifestyle Medicine: Analytic review, 6(6), 460478.

Brown, S. J. (2008). Evidence-based nursing: The research-practice connection. Sudbury, MA: Jones and Bartlett. Retrieved from https:/ / books.google.co.nz/books?hl=en\&lr=8*id=9JDFsgYs3mwC\&oi=fnd\&pg=PR1\&dq=Br own,+S.+J.+(2008).+Evidence-based+nursing:+The+researchpractice+connection.+Sudbury, +MA:+Jones+and+Bartlett.\&ots=woezxf9276\&sig=PpBvc3T A5dp8_jZUaulbK2vV4_g\#v=onepage\&q\& $\mathrm{f}=$ false

Engel-Yeger, B., Jarus, T., Anaby, D., \& Law, M. (2009). Differences in patterns of participation between youths with cerebral palsy and typically developing peers. American Journal of Occupational Therapy, 63(1), 96-104.

Fairbairn-Dunlop, P., and Makisi, G. (2003). Making our Place: Growing up PI in New Zealand. Palmerston North, New Zealand: Dunmore Press. Retrieved from https://trove.nla.gov.au/work/28038963?selectedversion=NBD24812826

Fong, S. S., Ha, A. S., Chan, T. W., \& Au, M. K. (2014). The enjoyment of physical activity determines body mass index in young people with physical disabilities. Open Journal of Preventive Medicine, 4, 241-249.

Groce, N. E. (2004). Adolescents and Youth with Disability: Issues and challenges. Asia Pacific Disability Rehabilitation Journal, 15(2), 13-32. Retrieved from http://discovery.ucl.ac.uk/15132/

Health Research Council of New Zealand (HRC). 2005. Guidelines on Pacific health research (3rd ed.). Auckland, New Zealand: Health Research Council of New Zealand. Retrieved from http://www.hrc.govt.nz/sites/default/files/Guidelines\%20on\%20Pacific\%20Health\%20Re search\%202005.pdf

Kim, S. Y. (2009). Assessing physical activity levels of students with disabilities in physical education? Journal of Physical Education, Recreation \& Dance, 80(3), 3-5. Retrieved from https://www.education.sa.gov.au/sites/g/files/net691/f/physical-education-report2010.pdf

King, G., Law, M., King, S., Rosebaum, P., Kertoy, M. K., \& Young, N. L. (2003). A conceptual model of the factors affecting the recreation and leisure participation of children with disabilities. Physical \& Occupational Therapy in Paediatrics, 23(1), 63-90. Retrieved from https://www.ncbi.nlm.nih.gov/pubmed/12703385

Kosma, M., Cardinal, B. J., \& Rintala, P. (2002). Motivating individuals with disabilities to be physically active. Quest, 54(2), 116-132. 
KristĖn, L., Patriksson, G., \& Fridlund, B. (2003). Parents' conceptions of the influences of participation in a sports programme on their children and adolescents with physical disabilities. European Physical Education Review, 9(1), 23-41.

Lindsay, S., \& Yantzi, N. (2014). Weather, disability, vulnerability, and resilience: Exploring how youth with physical disabilities experience winter. Disability and Rehabilitation 36(26), 2195-204.

Maher, C. A., Williams, M. T., Olds, T., \& Lane, A. E. (2007). Physical and sedentary activity in adolescents with cerebral palsy. Developmental Medicine and Child Neurology, 49(6), 450457.

Mila-Schaaf, K., Robinson, E., Schaaf, D., Denny, S., \& Watson, P. (2008). A health profile of Pacific youth: Findings of Youth 2000. A national secondary school youth health survey. Auckland, New Zealand: University of Auckland. Retrieved from https://www.fmhs.auckland.ac.nz/assets/fmhs/faculty/ahrg/docs/2001-pacific-reportoct08.pdf

Ministry of Health (2008a). Pacific peoples' experience of disability: A paper for the Pacific Health and Disability Action Plan review. Wellington, New Zealand: Ministry of Health. Retrieved from

http://www.moh.govt.nz/notebook/nbbooks.nsf/0/49C7E853E81FEC06CC257449007B3 DBA/\$file/pacific-youth-health-feb08.pdf

Ministry of Health (2008b). Pacific youth health: A paper for the Pacific Health and Disability Action Plan Review. Wellington, New Zealand: Ministry of Health. Retrieved from https://www.health.govt.nz/system/files/documents/publications/pacific-youth-health$\underline{\text { may08.pdf }}$

Ministry of Health (2008c). Pacific cultural competencies: A literature review. Wellington, New Zealand: Ministry of Health .Retrieved from https://www.health.govt.nz/system/files/documents/publications/pacific-culturalcompetencies-may08-2.pdf

Ministry of Health (2008d). Improving quality of health care for Pacific peoples. Wellington, New Zealand: Ministry of Health. Retrieved from https://www.health.govt.nz/system/files/documents/publications/improving-quality-ofcare-for-pacific-peoples-may08.pdf

Ministry of Health (2010). Faiva ora: National Pasifika disability plan. Wellington, New Zealand: Ministry of Health.

Ministry of Pacific Island Affairs (n.d.). About Pacific peoples in New Zealand. Wellington, New Zealand. Ministry of Pacific Island Affairs. Retrieved from http://archive.stats.govt.nz/browse_for_stats/people_and_communities/pacific_peoples/p acific-progress-health/references.aspx\#

Morris, P. J. (2008). Physical activity recommendations for children and adolescents with chronic disease. Current Sports Medicine Reports, 7(6), 353-358. 
Morse, J. M. \& Field, P. A. (1995). Qualitative research methods for health professionals. Thousand Oaks, CA: Sage. Retrieved from http://journals.sagepub.com/doi/abs/10.1177/104973299129121938

Murphy, N. A. \& Carbone, P. S. (2008). Promoting the participation of children with disabilities in sports, recreation, and physical activities. Paediatrics, 5(121), 1057-1061. Retrieved from http://www.rapidintellect.com/AEQweb/557415.pdf

Nooijen, C. F., Slaman, J., Stam, H. J., Roebroeck, M. E., \& Berg-Emons, R. J. (2014). Inactive and sedentary lifestyles amongst ambulatory adolescents and young adults with cerebral palsy. Journal of Neuroengineering and Rehabilitation, 11(1), 49.

Packer, T., Briffa, T., Downs, J., Ciccarelli, M., \& Passmore, A. (2006). PASCAD-Physical activity study of children and adolescents with disabilities in Perth, Western Australia. Retrieved from https://cdn.dal.ca/content/dam/dalhousie/pdf/faculty/faculty-healthprofessions/occupational-therapy/Publication_list_Jan_2017.pdf

Palisano, R. J., Orlin, M., Chiarello, L. A., Oeffinger, D., Polansky, M., Maggs, J., Gorton, G., Bagley, A., Tylkowski, C., Vogel, L., Abel, M., Stevenson, R. (2011). Determinants of intensity of participation in leisure and recreational activities by youth with cerebral palsy. Archives of Physical Medicine and Rehabilitation, Sep;92(9), 1468-76.

Pudney, W.W. E. (2014). Adolescent Volcanoes: Helping adolescents and their parents to deal with anger. London, U.K: Jessica Kingsley Publishers. Retrieved From http://apo.org.au/system/files/110311/apo-nid110311-439841.pdf

Sandelowski, M. (2000). Focus on research methods: Combining qualitative and quantitative sampling, data collection, and analysis techniques in mixed-method studies. Research in Nursing and Health, 23(3), 246-255.

Shkedy Rabani, A., Harries, N., Namoora, I., Al-Jarrah, M. D., Karniel, A., \& Bar-Haim, S. (2014). Duration and patterns of habitual physical activity in adolescents and young adults with cerebral palsy. Developmental Medicine and Child Neurology, Jul;56(7), 673-80. Retrieved from

https://www.ncbi.nlm.nih.gov/CBBresearch/Lu/Demo/PubTator/curator_mention.cgi?us er=bc5cdr\&pmid=24506509\&searchtype $=$ PubMed_Search\&query $=20561007[$ relatedto]\&pa ge $=58_{*}$ Chemical_display $=1 \&$ Disease $\_$display $=18$ tax $=$

Sport \& Recreation New Zealand. (2005). No exceptions: Strategy and implementation plan 20052009. Wellington, New Zealand. Retrieved from https://www.srknowledge.org.nz/research-completed/no-exceptions-strategy-andimplementation-plan-2005-2009/

Sport \& Recreation New Zealand. (2007). SPARC announces physical activity guidelines for children and young people. Wellington, New Zealand. Retrieved from https://sportnz.org.nz/assets/Uploads/attachments/About-us/Annual-Report-2007.pdf

Sport New Zealand. (2012). Sport and recreation in the lives of young New Zealanders. Wellington, New Zealand: Sport New Zealand.

Statistics New Zealand and Ministry of Pacific Island Affairs. (2011). Health and Pacific peoples in New Zealand. Wellington, New Zealand. Retrieved from

http://archive.stats.govt.nz/browse_for_stats/people_and_communities/pacific_peoples/p acific-progress-health.aspx 
Stubbs, D. \& Tawake, S. (2009). Pacific sisters with disabilities: At the intersection of discrimination. Suva, Fiji: UNDP Pacific Centre.

Sullivan-Bolyai, S., Bova, C., \& Harper, D. (2005). Developing and refining interventions in persons with health disparities: The use of qualitative description. Nursing Outlook, 53(3), 127-133.Retrieved from https://nyuscholars.nyu.edu/en/publications/developingand-refining-interventions-in-persons-with-health-disp

Taylor, N. F. (2014). Sedentary behaviour in adolescents and young adults with cerebral palsy. Developmental Medicine and Child Neurology, 56(7), 609-610.

Thomas, A., \& Bedini, L. A. (2011). Let me play! Girls with disabilities and physical activity. Women in Sport \& Physical Activity Journal, 2O(1), 104.

Tuffrey, C. (2013). Adolescents with physical disability: Seeing the individual in context. Archives of Disease in Childhood, 98(5), 373-377. Retrieved from http://www.academy.solent.nhs.uk/about-us/whos-who/catherine-tuffrey/

World Health Organization. (2010). Global recommendations on physical activity for health. Geneva, Switzerland: World Health Organization, 8-10. Retrieved from http://apps.who.int/iris/bitstream/handle/10665/44399/9789241599979_eng.pdf;jses sionid=FFB22C34CB7D9B1F032E094FFD794C36? sequence $=1$

World Health Organization. (2011). World report on disability. Geneva Switzerland: World Health Organization. Retrieved from https://www.ncbi.nlm.nih.gov/books/NBK304079/

Vaioleti, T. M. (2006). Talanoa research methodology: A developing position on Pacific research. Waikato Journal of Education, 12, 21-34. Retrieved from https://researchcommons.waikato.ac.nz/bitstream/handle/10289/6199/Vaioleti\%20Tal anoa.pdf?sequence $=18$ is Allowed $=\mathrm{y}$

Van Eck, M., Dallmeijer, A. J., Beckerman, H., Van Den Hoven, P. A., Voorman, J. M., \& Becher, J. G. (2008). Physical activity level and related factors in adolescents with cerebral palsy. Pediatric Exercise Science, 20(1), 95. Retrieved from https://www.ncbi.nlm.nih.gov/pubmed/18364538

Verschuren, O., Wiart, L., Hermans, D., \& Ketelaar, M. (2012). Identification of facilitators and barriers to physical activity in children and adolescents with cerebral palsy. The Journal of Pediatrics, 161(3), 488-494. 